\title{
THE EFFECT OF PROTOVERATRINE ON THE CARDIAC OUTPUT AND ON SOME REGIONAL CIRCULATIONS IN MAN ${ }^{1}$
}

\author{
By S. W. HOOBLER, T. G. KABZA, AND R. W. CORLEY 2 \\ (From the Department of Internal Medicine, University of Michigan Medical School, \\ Ann Arbor, Mich.)
}

(Submitted for publication May 5, 1954 ; accepted December 29, 1954)

Protoveratrine is a mixture of two purified alkaloids derived from veratrum album. According to Meilman and Krayer (1) it has a marked and reproducible depressor effect when given intravenously to hypertensive patients. This effect has been confirmed (2) and the drug has been administered in the long term management of severe hypertension (3). It therefore becomes important to know whether the depressor action of Protoveratrine $^{3}$ is a result of a reduction in cardiac output, or of a decrease in total peripheral resistance, and if the latter, what vascular area is chiefly involved. Observations bearing on these questions are presented herewith.

\section{METHODS}

The Protoveratrine was prepared for intravenous administration according to the method of Meilman and Krayer (1). Subjects were patients with essential or renal hypertension under the age of 50 and with casual diastolic blood pressures exceeding $110 \mathrm{~mm}$. of mercury. Except where indicated, they had not undergone supradiaphragmatic sympathectomy. The cardiac output was determined by the direct Fick method, the mixed venous sample being obtained in all instances from the pulmonary artery. Blood gas analyses were determined by the Hickam and Frayser technique (4) and expired air was collected over 1- to 2-minute periods in a spirometer and measured by a Beckman oxygen analyzer. Renal studies were performed by the usual clearance techniques, utilizing para-amino-hippurate and mannitol $(5,6)$. Peripheral blood flow was measured by the venous occlusion plethysmograph following the technique outlined by Abramson (7).

1 Supported by grants from Eli Lilly and Co., The $\mathrm{Na}$ tional Heart Institute of the U. S. Public Health Service, and the Michigan Heart Association.

2 Present address is 204 Holmcrest Street, Jackson, Michigan.

${ }^{8}$ Kindly supplied to us at first by Dr. Otto Krayer, Professor of Pharmacology, Harvard University Medical School, and later by Dr. Kenneth Kohlstaedt, Eli Lilly and Company.
RESULTS

\section{Effects on blood pressure and pulse rate}

Preliminary experience with Protoveratrine indicated that when an effective dose (1.2 to 1.6 mcg. per Kg.) was administered intravenously in single injections, a 10 to 20 per cent reduction in mean blood pressure usually occurred in the hypertensive patients. The lowering of pressure was associated with a marked bradycardia, which could be abolished by atropine sulphate $1 \mathrm{mg}$. intravenously. The blood pressure remained unchanged in some cases while in other instances it rose considerably following the atropine. No cases of heart block or cardiac irregularity were encountered after Protoveratrine. The reduction in blood pressure began in 5 to 10 minutes, reached a maximum in 7 to 15 minutes and gradually returned toward the initial control levels in the remaining 30 to 45 minutes. The patients experienced a few side effects, chief of which were paresthesias in the throat, over the face and upper thorax. Nausea and vomiting were not observed after single intravenous injections.

\section{Effect of the drug on cardiac output and peripheral resistance (Table I).}

In all cases there was a decline in cardiac output at the time of the lowest blood pressure, although in a few cases the blood pressure decline preceded the fall in output (E. B., S. P.). The data are presented in Table I for those patients who had a fall greater than 10 per cent in their mean blood pressures following injection of Protoveratrine. Three patients whose blood pressure did not fall were excluded from the table, since no significant alterations in the pulse rate or cardiac output occurred. The decline in cardiac output was associated with a decrease in heart rate, so that stroke volume usually remained unchanged. 
TABLE I

Effect of intravenous Protoveratrine on cardiac output in hypertensive subjects

\begin{tabular}{|c|c|c|c|c|c|c|c|c|c|c|c|c|}
\hline \multirow[b]{2}{*}{ Subj. } & \multirow[b]{2}{*}{$\begin{array}{l}\text { Time } \\
\text { (Min.) }\end{array}$} & \multirow[b]{2}{*}{$\begin{array}{c}\text { Pulse } \\
\text { rate }\end{array}$} & \multicolumn{3}{|c|}{ Blood press. $(\mathrm{mm} . \mathrm{Hg})$} & \multirow{2}{*}{$\begin{array}{c}\text { A-VO, } \\
\text { diff. } \\
\text { (Vol. \%) }\end{array}$} & \multicolumn{2}{|c|}{ Cardiac index } & \multicolumn{4}{|c|}{ Stroke vol. per. resist. } \\
\hline & & & S/D & Mean & $\begin{array}{c}\% \Delta \text { of } \\
\text { mean } B P\end{array}$ & & $\begin{array}{c}\text { L. } \\
\text { m. }\end{array}$ & $\% \Delta$ & $c c$. & $\% \Delta$ & $\begin{array}{c}\text { dymes/ } \\
\text { sec./cm.-s }\end{array}$ & $\% \Delta$ \\
\hline \multirow[t]{2}{*}{ E. B. } & \multirow{2}{*}{$\begin{array}{l}-14 \\
-7 \\
I . V . \\
+6 \\
+11 \\
+18 \\
+37 \\
+56\end{array}$} & \multirow{2}{*}{$\begin{array}{c}86 \\
84 \\
\text { PV (.14 mg.) } \\
74 \\
70 \\
72 \\
78 \\
84\end{array}$} & $\begin{array}{l}180 / 130 \\
187 / 128\end{array}$ & $\begin{array}{l}155 \\
158\end{array}$ & & $\begin{array}{l}4.8 \\
4.7\end{array}$ & $\begin{array}{l}3.16 \\
3.14\end{array}$ & & $\begin{array}{l}68 \\
70\end{array}$ & & $\begin{array}{l}1,135 \\
1,165\end{array}$ & \\
\hline & & & $\begin{array}{l}135 / 88 \\
122 / 80 \\
142 / 95 \\
162 / 118 \\
165 / 120\end{array}$ & $\begin{array}{l}112 \\
101 \\
118 \\
140 \\
142\end{array}$ & $\begin{array}{l}-28 \\
-36 \\
-25 \\
-10 \\
-9\end{array}$ & $\begin{array}{l}4.4 \\
5.1 \\
5.0 \\
4.7 \\
4.7\end{array}$ & $\begin{array}{l}3.42 \\
2.60 \\
2.75 \\
3.02 \\
3.05\end{array}$ & $\begin{array}{l}+9 \\
-17 \\
-13 \\
-4 \\
-3\end{array}$ & $\begin{array}{l}86 \\
69 \\
71 \\
72 \\
68\end{array}$ & $\begin{array}{r}+25 \\
0 \\
+3 \\
+4 \\
-1\end{array}$ & $\begin{array}{r}755 \\
900 \\
990 \\
1,070 \\
1,075\end{array}$ & $\begin{array}{l}-34 \\
-22 \\
-14 \\
-7 \\
-7\end{array}$ \\
\hline \multirow[t]{2}{*}{ E. Br. } & \multirow{2}{*}{$\begin{array}{l}-20 \\
-7 \\
I . V . \\
+11 \\
+20\end{array}$} & \multirow{2}{*}{$\begin{array}{c}78 \\
71 \\
\text { PV (.09 mg.) } \\
52 \\
51\end{array}$} & $\begin{array}{l}225 / 140 \\
240 / 140\end{array}$ & $\begin{array}{l}182 \\
190\end{array}$ & & $\begin{array}{l}4.5 \\
4.3\end{array}$ & $\begin{array}{l}2.61 \\
2.79\end{array}$ & & $\begin{array}{l}50 \\
59\end{array}$ & & $\begin{array}{l}2,475 \\
2,415\end{array}$ & \\
\hline & & & $\begin{array}{l}145 / 100 \\
130 / 95\end{array}$ & $\begin{array}{l}122 \\
112\end{array}$ & $\begin{array}{l}-34 \\
-40\end{array}$ & $\begin{array}{l}4.8 \\
5.2\end{array}$ & $\begin{array}{l}2.11 \\
1.93\end{array}$ & $\begin{array}{l}-22 \\
-28\end{array}$ & $\begin{array}{l}61 \\
57\end{array}$ & $\begin{array}{l}+13 \\
+6\end{array}$ & $\begin{array}{l}2,050 \\
2,065\end{array}$ & $\begin{array}{l}-16 \\
-16\end{array}$ \\
\hline \multirow[t]{2}{*}{ S. P. } & \multirow{2}{*}{$\begin{array}{l}-13 \\
-5 \\
I . V \\
+10 \\
+18 \\
+29 \\
+48\end{array}$} & \multirow{2}{*}{$\begin{array}{c}80 \\
80 \\
\text { PV (.13 mg.) } \\
66 \\
63 \\
65 \\
74\end{array}$} & $\begin{array}{l}254 / 140 \\
245 / 134\end{array}$ & $\begin{array}{l}197 \\
190\end{array}$ & & $\begin{array}{l}5.3 \\
5.1\end{array}$ & $\begin{array}{l}3.00 \\
3.03\end{array}$ & & $\begin{array}{l}63 \\
64\end{array}$ & & $\begin{array}{l}1,855 \\
1,775\end{array}$ & \\
\hline & & & $\begin{array}{l}197 / 99 \\
170 / 96 \\
190 / 107 \\
224 / 126\end{array}$ & $\begin{array}{l}148 \\
133 \\
148 \\
175\end{array}$ & $\begin{array}{l}-24 \\
-31 \\
-24 \\
-10\end{array}$ & $\begin{array}{l}4.7 \\
5.5 \\
5.4 \\
5.2\end{array}$ & $\begin{array}{l}3.14 \\
2.30 \\
2.52 \\
2.59\end{array}$ & $\begin{array}{l}+4 \\
-24 \\
-17 \\
-14\end{array}$ & $\begin{array}{l}80 \\
61 \\
65 \\
59\end{array}$ & $\begin{array}{l}+25 \\
-5 \\
+2 \\
-8\end{array}$ & $\begin{array}{l}1,335 \\
1,640 \\
1,660 \\
1,915\end{array}$ & $\begin{array}{l}-26 \\
-10 \\
-8 \\
+6\end{array}$ \\
\hline \multirow[t]{2}{*}{ J. L. } & \multirow{2}{*}{$\begin{array}{l}-12 \\
-44 \\
I . V \\
+19 \\
+27\end{array}$} & \multirow{2}{*}{$\begin{array}{c}87 \\
90 \\
\text { PV (.12 mg.) } \\
80 \\
79\end{array}$} & $\begin{array}{l}210 / 160 \\
210 / 160\end{array}$ & $\begin{array}{l}185 \\
185\end{array}$ & & $\begin{array}{l}4.1 \\
4.0\end{array}$ & $\begin{array}{l}3.48 \\
3.60\end{array}$ & & $\begin{array}{l}68 \\
68\end{array}$ & & $\begin{array}{l}1,490 \\
1,445\end{array}$ & \\
\hline & & & $\begin{array}{l}180 / 140 \\
175 / 140\end{array}$ & $\begin{array}{l}160 \\
158\end{array}$ & $\begin{array}{l}-14 \\
-15\end{array}$ & $\begin{array}{l}4.8 \\
4.6\end{array}$ & $\begin{array}{l}3.08 \\
3.07\end{array}$ & $\begin{array}{l}-13 \\
-13\end{array}$ & $\begin{array}{l}65 \\
66\end{array}$ & $\begin{array}{l}-4 \\
-3\end{array}$ & $\begin{array}{l}1,440 \\
1,440\end{array}$ & $\begin{array}{l}-2 \\
-2\end{array}$ \\
\hline \multirow[t]{2}{*}{ C. $\mathrm{K}$. } & \multirow{2}{*}{$\begin{array}{l}-11 \\
-44 \\
I . V . \\
+21 \\
+32 \\
+38\end{array}$} & \multirow{2}{*}{$\begin{array}{c}74 \\
74 \\
\text { PV (.11 mg.) } \\
66 \\
69 \\
71\end{array}$} & $\begin{array}{l}195 / 132 \\
198 / 135\end{array}$ & $\begin{array}{l}164 \\
166\end{array}$ & & $\begin{array}{l}4.7 \\
4.6\end{array}$ & $\begin{array}{l}3.63 \\
3.44\end{array}$ & & $\begin{array}{l}82 \\
78\end{array}$ & & $\begin{array}{l}1,295 \\
1,385\end{array}$ & \\
\hline & & & $\begin{array}{l}172 / 125 \\
182 / 130 \\
188 / 132\end{array}$ & $\begin{array}{l}148 \\
156 \\
160\end{array}$ & $\begin{array}{l}-10 \\
-5 \\
-3\end{array}$ & $\begin{array}{l}4.7 \\
4.7 \\
4.5\end{array}$ & $\begin{array}{l}3.01 \\
3.21 \\
3.41\end{array}$ & $\begin{array}{l}-15 \\
-9 \\
-4\end{array}$ & $\begin{array}{l}76 \\
78 \\
80\end{array}$ & $\begin{array}{r}-5 \\
-2 \\
0\end{array}$ & $\begin{array}{l}1,410 \\
1,395 \\
1,345\end{array}$ & $\begin{array}{r}+5 \\
+4 \\
0\end{array}$ \\
\hline \multirow[t]{2}{*}{ S. F. } & \multirow{2}{*}{$\begin{array}{l}-17 \\
-7 \\
I . v . \\
+5 \\
+10 \\
+30 \\
+48\end{array}$} & \multirow{2}{*}{$\begin{array}{c}73 \\
76 \\
\text { PV (.12 mg.) } \\
74 \\
69 \\
69 \\
74\end{array}$} & $\begin{array}{l}171 / 119 \\
175 / 118\end{array}$ & $\begin{array}{l}145 \\
146\end{array}$ & & $\begin{array}{l}4.8 \\
4.7\end{array}$ & $\begin{array}{l}2.80 \\
2.83\end{array}$ & & $\begin{array}{l}64 \\
62\end{array}$ & & $\begin{array}{l}1,485 \\
1,475\end{array}$ & \\
\hline & & & $\begin{array}{l}138 / 107 \\
122 / 97 \\
145 / 103 \\
153 / 105\end{array}$ & $\begin{array}{l}122 \\
110 \\
124 \\
129\end{array}$ & $\begin{array}{l}-16 \\
-24 \\
-15 \\
-11\end{array}$ & $\begin{array}{l}5.0 \\
5.6 \\
5.1 \\
5.7\end{array}$ & $\begin{array}{l}2.57 \\
2.24 \\
2.58 \\
2.32\end{array}$ & $\begin{array}{l}-9 \\
-21 \\
-8 \\
-18\end{array}$ & $\begin{array}{l}58 \\
54 \\
62 \\
52\end{array}$ & $\begin{array}{l}-8 \\
-14 \\
-2 \\
-17\end{array}$ & $\begin{array}{l}1,360 \\
1,410 \\
1,380 \\
1,590\end{array}$ & $\begin{array}{l}-8 \\
-5 \\
-7 \\
+7\end{array}$ \\
\hline
\end{tabular}

In the first three patients in whom the blood pressure was markedly reduced, a decrease in total systemic peripheral resistance also occurred. In the remainder, the percentage of reduction in blood pressure was similar to the reduction in cardiac output, so that the total peripheral resistance did not change.

In order to study the effects of a more gradual reduction in blood pressure, the cardiac output was followed for three hours in one patient given the drug orally (Figure 1 ). In this case, reduction of pressure was not associated with a decline in cardiac output and there was, consequently, a marked fall in total peripheral resistance.
Cardiac work (calculated as the product of cardiac output and mean blood pressure) was reduced in all cases given Protoveratrine.

\section{Effects on renal circulation}

Six of ten patients studied showed reductions exceeding 10 per cent in mean blood pressure after intravenous Protoveratrine (Table II). In these cases no consistent changes in renal plasma flow occurred. Consequently, a slight reduction in renal resistance was observed. Glomerular filtration rate fell more than 10 per cent in four of the ten cases, and the filtration fraction was correspondingly lower. The most striking altera- 


\section{HEMODMNAMIC EFFECTS OF ORAL PROTOVERATRINE IN HYPERTENSION}

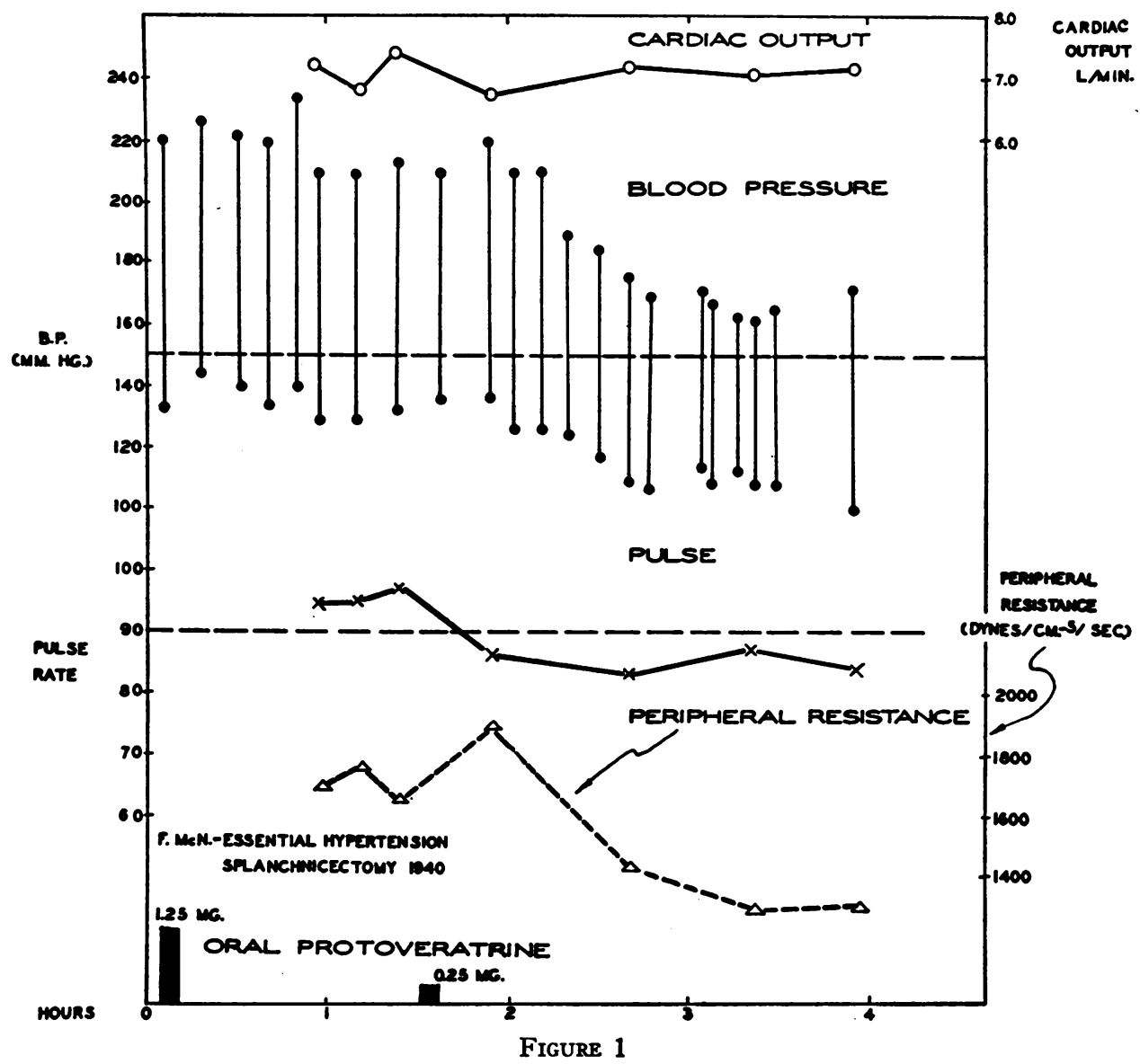

TABLE II

The effects of Protoveratrine on renal circulation in hypertension *

\begin{tabular}{|c|c|c|c|c|c|c|c|c|c|c|c|c|}
\hline \multirow[b]{2}{*}{ Subj. } & \multicolumn{2}{|c|}{$\begin{array}{l}\text { Mean blood } \\
\text { pressure }\end{array}$} & \multicolumn{2}{|c|}{$\begin{array}{l}\text { Renal plasma } \\
\text { flow }\end{array}$} & \multicolumn{2}{|c|}{$\begin{array}{c}\text { Renal } \\
\text { resistance }\end{array}$} & \multicolumn{2}{|c|}{$\begin{array}{c}\text { Glomerular } \\
\text { filtration rate }\end{array}$} & \multicolumn{2}{|c|}{$\begin{array}{c}\text { Filtration } \\
\text { fraction }\end{array}$} & \multicolumn{2}{|c|}{ Urine flow } \\
\hline & $\begin{array}{l}\text { Control } \\
\mathbf{M m} . \mathbf{H g}\end{array}$ & $\begin{array}{l}\text { After } \\
\text { P.V. } \\
\% \Delta\end{array}$ & $\begin{array}{l}\text { Control } \\
c c . / \min \text {. }\end{array}$ & $\begin{array}{l}\text { After } \\
\text { P.V. } \\
\% \Delta\end{array}$ & $\begin{array}{l}\text { Control } \\
\text { Mean BP } \\
\text { RPF }\end{array}$ & $\begin{array}{l}\text { After } \\
\text { P.V. } \\
\% \Delta\end{array}$ & $\begin{array}{l}\text { Control } \\
c c . / \min \text {. }\end{array}$ & $\begin{array}{l}\text { After } \\
\text { P.V. } \\
\% \Delta\end{array}$ & Control & $\begin{array}{l}\text { After } \\
\text { P.V. } \\
\% \dot{\Delta}\end{array}$ & $\begin{array}{l}\text { Control } \\
\text { cc. } / \text { min. }\end{array}$ & $\begin{array}{l}\text { After } \\
\text { P.V. } \\
\% \Delta\end{array}$ \\
\hline $\begin{array}{l}\text { H. S. } \\
\text { P. J. } \\
\text { L. L. } \\
\text { M. B. } \\
\text { B. L. } \\
\text { M. A. } \\
\text { F. C. } \\
\text { M. D. } \\
\text { M. W. } \\
\text { C. F. }\end{array}$ & $\begin{array}{l}149 \\
159 \\
223 \\
145 \\
146 \\
157 \\
182 \\
188 \\
167 \\
162\end{array}$ & $\begin{array}{l}-18 \\
-16 \\
-14 \\
-14 \\
-13 \\
-11 \\
-8 \\
-6 \\
-5 \\
-3\end{array}$ & $\begin{array}{l}513 \\
180 \\
403 \\
525 \\
370 \\
359 \\
274 \\
306 \\
466 \\
299\end{array}$ & $\begin{array}{l}+2 \\
+16 \\
-11 \\
+3 \\
+2 \\
-3 \\
-11 \\
-4 \\
+11 \\
-7\end{array}$ & $\begin{array}{l}.29 \\
.88 \\
.55 \\
.27 \\
.39 \\
.43 \\
.66 \\
.61 \\
.35 \\
.54\end{array}$ & $\begin{array}{r}-19 \\
-24 \\
-3 \\
-16 \\
-14 \\
-8 \\
3 \\
-1 \\
-14 \\
3\end{array}$ & $\begin{array}{r}118 \\
55 \\
104 \\
108 \\
90 \\
97 \\
63 \\
95 \\
115 \\
73\end{array}$ & $\begin{array}{l}-6 \\
+11 \\
-16 \\
-12 \\
-6 \\
-12 \\
-13 \\
-6 \\
+3 \\
-1\end{array}$ & $\begin{array}{l}.23 \\
.31 \\
.26 \\
.21 \\
.24 \\
.26 \\
.23 \\
.31 \\
.25 \\
.24\end{array}$ & $\begin{array}{l}-9 \\
-6 \\
-8 \\
-14 \\
-4 \\
=8 \\
-4 \\
-3 \\
-8 \\
8\end{array}$ & $\begin{array}{l}4.2 \\
2.4 \\
3.3 \\
4.7 \\
3.1 \\
4.8 \\
7.8 \\
3.8 \\
8.9 \\
4.6\end{array}$ & $\begin{array}{r}0 \\
+8 \\
-58 \\
-43 \\
-29 \\
-60 \\
-63 \\
-34 \\
-58 \\
-43\end{array}$ \\
\hline $\begin{array}{l}\text { Mean Value } \\
\% \text { Change }\end{array}$ & 168 & -11 & 370 & 0 & .50 & -9 & 92 & -6 & .25 & -6 & 4.8 & -38 \\
\hline
\end{tabular}

* All control observations represent the mean of three ten-minute periods immediately preceding the intravenous injection of Protoveratrine. Data listed as "after Protoveratrine" represent the mean value of two or three successive urine collection periods starting ten minutes after intravenous Protoveratrine and running continuously up to 30 to $\mathbf{4 0}$ minutes after the injection, depending on the duration of significant BP reduction. Renal plasma flow was determined by para-amino-hippurate clearance and glomerular filtration rate by mannitol clearance.

P.V. = Protoveratrine. 


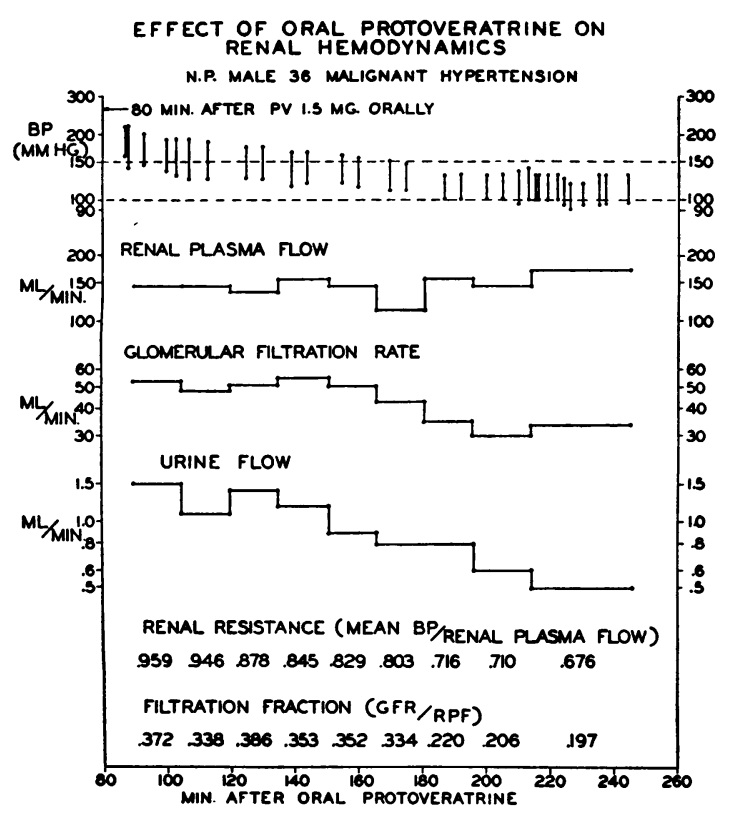

Figure 2 tions were in urine flow, which decreased an average of 38 per cent. Since filtration rate was reduced only 6 per cent, it is probable that the reductions were not entirely the result of a decreased filtration volume, but also involved increased tubular reabsorption of water. Oliguria was likewise noted in cases receiving Protoveratrine in whom the blood pressure reduction was minimal.

A more prolonged study was made of the effects of orally administered Protoveratrine on the renal function in one patient with severe malignant hypertension (Figure 2). The same qualitative changes were observed in this individual as are presented in Table II following effective intravenous injections.

\section{Effects on circulation in the extremities}

The effect of Protoveratrine on the blood flow in the foot and forearm was determined in 21 re-

TABLE III

The effects of Protoveratrine on peripheral blood flow in hypertension

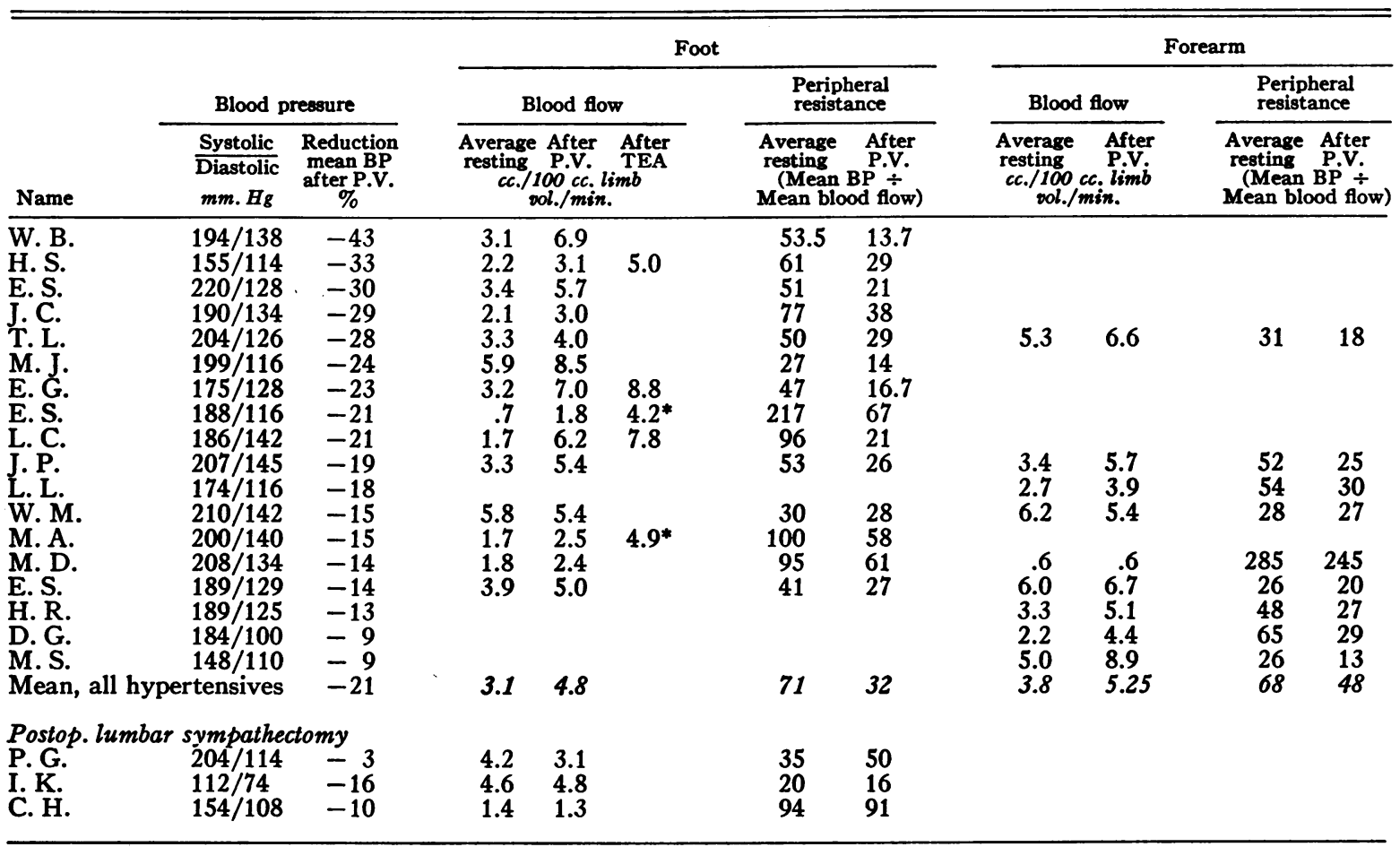

* Indicates that tetraethylammonium chloride was given at time of maximum effect from Protoveratrine. In all cases 200 to $300 \mathrm{mg}$. of tetraethylammonium chloride were given i.v. so that ganglionic blockade was judged incomplete. Mean BP declines were minimal with tetraethylammonium chloride, never exceeding -10 per cent. Mean BP represents systolic plus diastolic $\div 2$. Average values quoted represent the mean of 5 consecutive observations at 30 sec. intervals before and at the time of maximum drug action.

The numbers in italics represent mean values the differences of which are statistically significant with a probability of $1: 20$ or greater by analysis of variance. 
cumbent patients observed after a half hour of quiet rest in a room maintained at an average temperature of 70 to $74^{\circ} \mathrm{F}$. (Table III). With three exceptions there was a consistent increase in blood flow to the foot averaging 55 per cent and a lesser increase of 36 per cent in the forearm circulation, with a marked decrease in vascular resistance in both areas. The increases in blood flow were more marked following tetraethylammonium in a moderate dosage, and when the TEA was given at the height of Protoveratrine vasodilatation, further increases occurred (E. S. and M. A., Table III). Three patients were selected whose lower extremities had been denervated by lumbar sympathectomy so effectively that postoperative testing with TEA revealed no increase in blood flow. After the administration of comparable doses of Protoveratrine to these individuals, no increase in blood flow to the foot was observed and local vascular resistance either increased or was unchanged.

\section{DISCUSSION}

These observations indicate that moderate reductions in blood pressure after parenterally administered Protoveratrine are associated with a decline in cardiac output, while more marked reductions in blood pressure involve, in addition, decreases in total peripheral resistance. This is in agreement with other observations that cardiac output decreases after intravenously administered Protoveratrine (8). In a somewhat similar study of veratrum viride derivatives (9) no change in cardiac output occurred in the absence of congestive failure. However, these studies were performed at later intervals after administration of the drug and perhaps correspond more closely to our observation in the patient followed for three hours after the gradual reduction of blood pressure by the oral route, in which case a reduction in output was also not observed.

The mechanism whereby the reduction in cardiac output occurs cannot be established in the studies here reported. It is not likely that the drug has a depressant effect on the ventricular musculature, since at least in the heart-lung preparation (10) and in the various studies in animals it has not been shown to exert a negative inotropic effect. The reductions in peripheral and possibly in central venous pressure caused by veratrum alkaloids are probably of insufficient magnitude to be the sole cause of the lowered output and the fact that stroke volume is not appreciably reduced is further evidence against a direct cardiac action or a decrease in venous return. If increase in pulse rate alone can elevate the cardiac output as would appear to be the case from McMichael's studies on atropine (11), it might be postulated that marked decreases following Protoveratrine might depress the output in similar fashion.

Changes in vascular resistance following Protoveratrine were measured in the renal and peripheral circuits. In the kidneys, a decrease in renal resistance, due largely to the fall in blood pressure, occurred. Similar observations have been recorded by other investigators employing either Veriloid (9) or Protoveratrine (12). What vasodilatation there was may have been a passive response to the reduced blood pressure since the renal vessels are known to have considerable autonomous capacity to dilate as blood pressure falls. A moderate decline in mannitol clearance was also observed (9), but could not be confirmed when inulin was used to measure the glomerular filtration rate. This discrepancy was attributed to reabsorption of mannitol during oliguria induced by veratrum.

Blood flow is increased and vascular resistance is decreased in the forearm and foot. The vasodilatation, at least so far as the foot is concerned, depends on an intact sympathetic innervation since it can no longer be demonstrated in the sympathectomized extremity. This observation is in accordance with that of the authors previously cited (9).

In conclusion, it should be emphasized that the observations in acute studies may not necessarily apply to the effects of chronic administration of veratrum alkaloids. It is possible that under the prolonged effects of hypotension compensatory vasodilatation occurs, and the circulatory system reaches a new equilibrium with the restoration of cardiac output to normal. Thus, prolonged reduction in blood pressure following oral administration in one case was not accompanied by the decreases in output seen in acute experiments. Similarly, the inhibition of urine flow seen after acute administration is said to decrease after prolonged administration (13). Finally, despite a slight decrease in glomerular filtration rate in 
some acute experiments, no progression of azotemia was observed in the chronic treatment of nephritic patients with this drug (3).

\section{CONCLUSIONS}

1. Protoveratrine, administered intravenously, produced a moderate decline in cardiac output, a definite decline in cardiac work, and sometimes a decrease in total peripheral resistance.

2. Renal blood flow was unchanged but glomerular filtration rate fell slightly and urine flow markedly in acute experiments.

3. Blood flow in the foot and forearm was increased moderately when the sympathetic nerves to the extremity were intact.

\section{REFERENCES}

1. Meilman, E., and Krayer, O., Clinical studies on veratrum alkaloids. I. The action of Protoveratrine and Veratridine in hypertension. Circulation, 1950, 1, 204.

2. Hoobler, S. W., and Corley, R. W., The hypotensive action of Protoveratrine. Univ. of Mich. Med. Bull., 1950, 16, 362.

3. Hoobler, S. W., Corley, R. W., Kabza, T. G., and Loyke, H. F., Treatment of hypertension with oral Protoveratrine. Ann. Int. Med., 1952, 37, 465.

4. Hickam, J. B., and Frayser, R., Spectrophotometric determination of blood oxygen. J. Biol. Chem., 1949, 180, 457.
5. Smith, H. W., Finkelstein, N., Aliminosa, L., Crawford, B., and Graber, M., The renal clearances of substituted hippuric acid derivatives and other aromatic acids in dog and man. J. Clin. Invest., 1945, 24, 388.

6. Corcoran, A. C., and Page, I. H., A method for the determination of mannitol in plasma and urine. J. Biol. Chem., 1947, 170, 165.

7. Abramson, D. I., Vascular Responses in the Extremities of Man in Health and Disease. Chicago, Univ. of Chicago Press, 1944.

8. Currens, J. H., Myers, G. S., and McGinty, J. S., Observations on the use of Protoveratrine in hypertensive vascular disease. J. Clin. Invest., 1952, 31, 623.

9. Freis, E. D., Stanton, J. R., Culbertson, J. W., Litter, J., Halperin, M. H., Burnett, C. H., and Wilkins, R. W., The hemodynamic effects of hypotensive drugs in man. I. Veratrum viride. J. Clin. Invest., 1949, 28, 353.

10. Krayer, O., and Mendez, R., Studies on veratrum alkaloids. I. The action of veratrine upon the isolated mammalian heart. J. Pharmacol. \& Exper. Therap., 1942, 74, 350.

11. McMichael, J., Circulatory failure studied by means of venous catheterization. Advances Int. Med., 1947, 2, 64.

12. Meilman, E., Clinical studies on veratrum alkaloids. III. The effect of Protoveratrine on renal function in man. J. Clin. Invest., 1953, 32, 80.

13. Assali, N. S., Kistner, R. W., and Garber, S. T., The effect of veratrum viride on the urine volume, blood pressure and pulse rate in normal and toxemic pregnancy. Am. J. Obst. \& Gynec., 1949, 58, 90. 